\title{
Current issues on the genetic implications and treatment of androgenic alopecia
}

\section{Aspecte actuale ale implicaţiilor genetice şi tratamentului alopeciei androgenice}

Ana Maria Alexandra STĂNESCU ${ }^{1}$, Constantin ŞTEFANI ${ }^{1,2}$, loana Veronica GRĂJDEANU ${ }^{1}$, Alexandra TOTAN ${ }^{1}$, Daniela MIRICESCU ${ }^{1}$, Bogdan ŞERBAN ${ }^{1}$, Gina GHEORGHE ${ }^{1}$, Ovidiu Gabriel BRATU ${ }^{1,2}$, Camelia Cristina DIACONU ${ }^{1,3}$

${ }^{1}$ Universitatea de Medicină şi Farmacie „Carol Davila“, Bucureşti, România

${ }^{2}$ Spitalul Universitar de Urgenţă Militar Central „Dr. Carol Davila“, Bucureşti, România

${ }^{3}$ Spitalul Clinic de Urgenţă, Bucureşti, România

\begin{abstract}
Androgenic alopecia is the most common form of hair loss, hair loss is progressively occurring, affecting all races. In addition to the major psychological impact and impairment of quality of life, patients with early androgenic alopecia may subsequently suffer from severe coronary heart disease and metabolic syndrome. Androgenic alopecia is a multifactorial dermatological disorder, with a complex genetic inheritance. Treatment is a challenge both for doctor and patient.
\end{abstract}

Keywords: androgenic alopecia, genetics, treatment

\section{REZUMAT}

Alopecia androgenică reprezintă cea mai frecventă formă de cădere a părului, în care căderea părului se realizează progresiv, putând afecta toate rasele. Pe lângă impactul psihologic major şi afectarea calității vieții, pacienții cu alopecie androgenică precoce pot suferi ulterior de boli coronariene severe şi sindrom metabolic. Alopecia androgenică este o afecțiune dermatologică multifactorială, cu o moştenire genetică complexă. Tratamentul reprezintă o provocare atât pentru medic, cât şi pentru pacient.

Cuvinte cheie: alopecia androgenică, genetică, tratament

\section{INTRODUCERE}

Alopecia androgenică (androgenetică) este o tulburare genetică, frecventă, ce are o predispoziţie către sexul masculin, însă există şi femei care suferă de această afecţiune. Alopecia androgenică reprezintă cea mai frecventă formă de cădere a părului. Căderea părului se realizează progresiv, putând afecta toate rasele.

În general, incidenţa bolii creşte o dată cu vârsta. La caucazieni, afectează până la $80 \%$ dintre bărbaţi şi 50\% dintre femei (1). În India, prevalenţa la bărbaţii cu vârste cuprinse între 30 şi 50 de ani a fost estimată la 58\% (2). 
Pentru a evalua severitatea şi amploarea alopeciei androgenice, de obicei se utilizează scara Ludwig la persoanele de sex feminin şi scara Hamilton-Norwood la persoanele de sex masculin $(3,4)$.

Atât bărbaţii, cât şi femeile au niveluri crescute de receptori androgeni şi activitate crescută a alfareductazei de tip I şi II în zona frontală a scalpului, comparativ cu foliculii de păr localizaţi în zona occipitală, care au niveluri mai mari de aromatază. Activitatea alfa-reductazei de tip I şi II în foliculii de păr frontali este de trei ori mai mare la bărbaţi decât la femei, alopecia androgenică masculină fiind considerată o afecţiune dependentă de androgeni; cu toate acestea, rolul semnalizării androgenilor la femei rămâne incert $(5,6)$.

Pe lângă impactul psihologic major şi afectarea calităţii vieţii, pacienţii cu alopecie androgenică precoce pot suferi ulterior de boli coronariene severe şi sindrom metabolic. Persoanele cu un indice de masă corporală crescut pot suferi de alopecie androgenică severă $(7,8,9)$.

Fiecare fir de păr îşi are originea într-un folicul de păr, iar ciclul de creştere a părului, care este realizat în patru faze, defineşte creşterea sa individuală şi asincronă. Miniaturizarea foliculului pilos este semnul caracteristic alopeciei androgenice, această anomalie fiind de obicei ireversibilă, deşi în unele cazuri sunt posibile revenirea parţială şi o inversare a miniaturizării (10).

\section{ASPECTE GENERALE}

La toţi pacienţii suspectaţi de alopecie androgenică trebuie să se efectueze un istoric amănunţit, care să includă: vârsta de debut a căderii părului, istoricul căderii părului la rude (atât paterne, cât şi materne), afecţiuni medicale precum sindromul metabolic şi rezistenţa la insulină, aportul de steroizi anabolici, sub formă de izolate din zer pur sau shake-uri proteice, şi statusul de fumători (2).

În general, modelul căderii părului şi istoricul sunt de obicei suficiente pentru a pune diagnosticul corect. Pentru siguranţă se pot utiliza teste clinice precum: dermatoscopia, testul tragerii de păr şi tricoscopia.

În general, nu sunt necesare investigaţii de laborator pentru stabilirea diagnosticului. Cu toate acestea, la femei, pentru a exclude alte afecţiuni de bază, se pot efectua următoarele determinări: testosteron, sulfat de dehidroepiandrosteron, insulină şi prolactină. în mod normal, biopsia nu este recomandată, dar în anumite cazuri se poate efectua biopsia, având un caracter informativ în alopecia areata sau lichen planus.

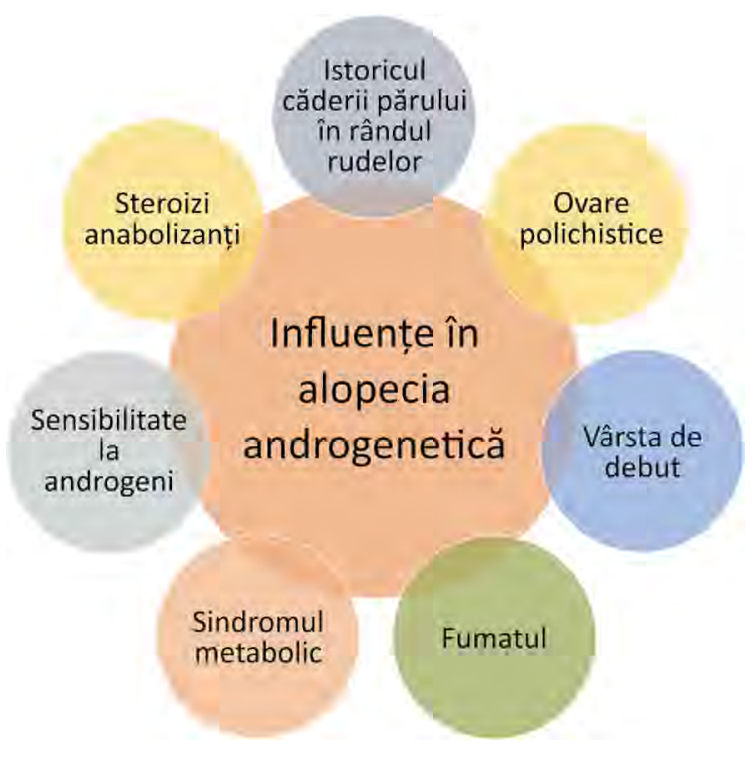

FIGURA 1. Factori care influențează diagnosticul alopeciei androgenice

Aproape toţi pacienţii cu alopecie au calitatea vieţii scăzută, scăderea stimei de sine având un impact major. În funcţie de impactul emoţional şi de stadiul alopeciei, se poate interveni prin consiliere, psihoterapie sau terapia cu anxiolitice în cazurile severe $(11,12,13)$.

Nu există dovezi clare care să sprijine utilizarea suplimentelor orale de aminoacizi, biotină, zinc şi alţi micronutrienţi în căderea părului de orice origine (11).

\section{ASPECTE GENETICE ACTUALE}

Deşi alopecia androgenică este mediată de androgeni, predispoziţia genetică joacă un rol important în etiologia sa. Genetica alopeciei androgenice este complexă, genele AR şi 5-alfa reductază sunt candidaţi atractivi pentru alopecia androgenică.

Există dovezi că atât enzimele 5-alfa reductaza, cât şi receptorul de androgeni sunt foarte exprimaţi în foliculii cheliei, în comparaţie cu foliculii nebaldanţi de pe acelaşi scalp, care se datorează diferitelor gene care codifică 5 -alfa reductaza de tip I şi II $(14,15)$.

Heilmann şi colaboratorii au arătat asocierea la nivelul genomului în alopecia androgenică, identificând semnale puternice de asociere în cromozomul X; atât gena $A R$, cât şi receptorul ectodysplasin A2 (locus în Xq11-q12) au arătat semnale puternice pentru alopecia androgenică (16).

Un nivel ridicat este asociat genei AR, care poate conferi până la $40 \%$ din riscul genetic total (17). Polimorfismele cu un singur nucleotid, variaţiile 
numărului de copii şi repetările triplete sunt printre polimorfismele care au fost studiate în legătură cu alopecia androgenetică. Gena AR se pare că este asociată în mod special cu alopecia androgenetică la bărbaţi (14). Sunt evidenţiate anumite contradicţii genetice în unele studii, precum studiul lui Hillmer şi colaboratorii, care au arătat că pacienţii cu alopecie androgenetică prezintă repetarea triplă de poliglicină GGN, în timp ce Ellis şi colaboratorii au arătat că aceste repetări de poliglicină nu conferă susceptibilitate pentru alopecia androgenetică; inclusiv analizele variaţiilor de număr de copii în AR sugerează că repetările de poliglicină nu sunt implicate în alopecia androgenetică $(18,19)$. Deşi rolul EDA2R în alopecia androgenetică nu este clar, analizele statistice arată că asocierea markerilor în EDA2R şi AR par să fie rezultatul dezechilibrului legăturii (20).

Localizarea AR pe cromozomul $X$ şi semnalul puternic de asociere al EDA2R evidenţiază importanţa liniei materne în moştenirea alopeciei androgenetice (18). Aceste descoperiri subliniază importanţa genei receptorului androgenilor responsabili pentru riscul crescut de alopecie androgenetică la bărbaţi, care au fost confirmate în mai multe studii independente.

Studiile de asociere la scară largă a genomului (scanarea markerilor pe un set complet de ADN genomic din multe cazuri şi controale pentru a determina variaţiile genetice asociate cu o trăsătură sau o anumită boală prin tehnologia microarray) au fost utilizate pentru a evalua moştenirea complexă a alopeciei androgenetice (21).

Heilmann şi colaboratorii au identificat patru loci de risc pentru alopecie androgenetică, localizate în 2q35, 3q25.1, 5q33.3 şi 12p12.1, cel mai puternic semnal de asociere a fost observat la $2 q 35$, care conţine gena WNT10A, ce are un efect genotipic asupra expresiei foliculului de păr (16). Li şi colaboratorii au identificat 6 noi loci de risc pentru alopecie androgenetică în 1p36.22, 2q37, 7p21.1, 7q11.22, 17q21.31 şi 18q21.1 şi o asociere puternică pentru alopecia androgenetică în 20p11 şi gena AR (22).

S-au descoperit că diverse gene precum BMP2, efrinA3, PGDS, PGD2, BDNF, proteina neurotrofină-3, factorul de creştere neuronală $\beta$, ASS1 şi GSN sunt exprimate în mod diferenţiat în cultura de celule din papile dermice şi în probele de biopsie a scalpului de la pacienţi cu alopecie androgenetică, putând fi implicate în dezvoltarea alopeciei androgenetice, fie ca promotori de creştere a părului, fie ca inhibitori $(23,24)$.

Garza şi colaboratorii au efectuat o analiză globală de expresie microarray prin biopsii din regiu- nile cheliei şi din regiunile occipitale la pacienţi cu alopecie androgenetică, găsind 250 de transcrieri exprimate în mod diferit, însă numai supraexpresia sintezei prostaglandinei a fost relevantă şi a ajuns la concluzia că produsul PGDS prostaglandină D2 inhibă creşterea părului (23). Există şi opinii contradictorii care susţin că nu există dovezi genetice pentru contribuţia prostaglandinelor la etiologia alopeciei androgenetice (16).

Midorikawa şi colaboratorii au constatat că nivelul crescut de androgeni a dus la un feedback negativ al expresiei genice a căii Notch, ceea ce a dus la miniaturizarea foliculului pilos şi la supraexpresia genei AR (24).

Puţine studii au evaluat rolul epigeneticii asupra fiziologiei foliculilor de păr şi etiologiei androgenetice a alopeciei. Cobb şi colaboratorii au investigat modelele de metilare pe gena AR în foliculii de păr occipital şi au observat o creştere a metilării genelor AR în foliculii occipitali, sugerând că o metilare a genei AR crescută protejează foliculii occipitali împotriva miniaturizării şi a căderii părului (25).

\section{ASPECTE TERAPEUTICE ACTUALE}

Minoxidilul rămâne elementul principal al terapiei pentru alopecia androgenică. Este folosit în principal la bărbaţi, se poate utiliza şi la femei, însă trebuie avut în vedere riscul de hipertricoză. Minoxidilul se poate utiliza în combinaţie cu preparate topice precum procapil, capexil, aminexil.

Inhibitori de 5-alfa reductază. Minoxidilul şi finasteridul sunt medicamentele aprobate pentru tratamentul căderii părului. Finasteridul $1 \mathrm{mg}$ prezintă rezultate mai bune decât minoxidilul în ceea ce priveşte creşterea părului. Finasteridul se utilizează zilnic timp de 6-12 luni. Răspunsul la tratament trebuie evaluat după 6 luni, deşi la unii pacienţi poate dura până la 12 luni pentru a deveni evident (2). Finasteridul este contraindicat la femeile de vârstă reproductivă, din cauza efectelor teratogene ale acesteia.

Terapia cu plasmă bogată în plachete (PRP) poate fi utilizată, dar numai ca adjuvant pentru minoxidil sau finasterid, şi nu ca monoterapie. Mecanismul terapiei PRP implică proliferarea celulelor papilei dermice induse de factorii de creştere ai PRP activat. Această terapie conţine diverşi factori de creştere şi citokine care îmbunătăţesc capacitatea inerentă a organismului de reparare şi regenerare, fiind utilizată de obicei pentru tratarea cicatricilor acneice, rănilor care nu se vindecă, căderii părului şi îmbunătăţirea supravieţuirii grefei $(26,27)$. În transplantul de păr, PRP poate fi o solu- 
ţie bună pentru grefe, care nu dăunează pacienţilor, cu toate acestea poate fi utilizată pentru cel mult 6 luni.

Terapia hormonală, cum ar fi utilizarea de antiandrogeni în alopecia androgenică la persoanele de sex masculin, nu s-a dovedit a fi foarte eficientă. Singura indicaţie bazată pe dovezi este utilizarea acetatului de ciproteronă la pacienţii de sex feminin cu dovezi clinice şi biochimice de hiperandrogenism (2).

Transplantul de păr - trebuie avută o grijă sporită în următoarele situaţii: pacienţi tineri cu alopecie cu evoluţie timpurie şi pacienţi cu Norwood gradul VI sau VII cu densitatea părului scăzută. Criterii de considerat pentru transplantul de păr: clasificarea gradului 3 Norwood; căderea părului stabilă care nu progresează rapid; eşecul unui tratament medical adecvat; la vârsta sub 25 de ani, transplantul trebuie făcut numai în cazurile de chelie extinsă; căderea părului bitemporal sau chelia părului frontal (28).

Procedurile de transplant de păr sunt de două tipuri: transplantul de unităţi foliculare şi extracţia de unităţi foliculare. Transplantul de unităţi folicu- lare poate acoperi suprafeţe mai mari, oferă grefe de calitate bună şi fină, este semnificativ mai dureros, este incomod pentru pacient din cauza cicatricii liniare, doar zona occipitală centrală este zona donatoare. Extracţia unităţii foliculare este mai uşor de efectuat, permite vindecarea rapidă a zonei donatorului, nu provoacă cicatrici, este relativ nedureros, procedura necesită mai mult timp decât transplantul de unităţi foliculare $(29,30)$.

\section{CONCLUZII}

Alopecia androgenică este o afecţiune dermatologică multifactorială, cu o moştenire genetică complexă. O prevalenţă mai mare a sindromului metabolic este observată la bărbaţii cu alopecie androgenetică cu debut precoce. Terapiile actuale sunt de lungă durată, iar unele dintre acestea sunt invazive. Pentru noi abordări terapeutice, sunt necesare mai multe studii, inclusiv genetice.

\section{Mențiune}

Toţi autorii au avut contribuţie egală în realizarea articolului.

Conflict of interest: none declared Financial support: none declared

\section{BIBLIOGRAFIE}

1. Heilmann $S$, Brockschmidt FF, Hillmer AM, Hanneken S, Eigelshoven S, Ludwig KU et al. Evidence for a polygenic contribution to androgenetic alopecia. Br J Dermatol 2013; 169:927-30.

2. Kaliyadan F, Nambiar A, Vijayaraghavan S. Androgenetic alopecia: An update. Indian J Dermatol Venereol Leprol. 2013;79:613-25.

3. Guarrera M, Cardo P, Arrigo P, Rebora A. Reliability of hamilton-norwood classification. Int J Trichology 2009;1:120-2.

4. Anghel R, lorga L, Marcu D et al. The role of Bosniak classification in the assessment of renal cystic masses and in the therapeutical protocol. Arch Balk Med Union 2018; 53(3):445-448.

5. Sawaya ME, Price VH. Different levels of 5alpha-reductase type I and II, aromatase, and androgen receptor in hair follicles of women and men with androgenetic alopecia. J Invest Dermatol 1997; 109:296-300.

6. Ioannides D, Lazaridou E. Female pattern hair loss. Curr Probl Dermatol 2015; 47:45-54

7. Clarke P. Male baldness. Aust Fam Physician. 2016;45:186-8.

8. Stănescu AMA, Matei A, Grăjdeanu IV, Appiah EA, Paparău C, Giurcăneanu C. Asocierea între psoriazis şi sindromul metabolic, corelată cu deficitul vitaminei D în ambele afecţiuni. Revista Medicală Română 2016; LXIII(1):81-85.

9. Stănescu AMA, Matei A, Grăjdeanu IV, Appiah EA, Giurcăneanu C. Multipli factori de interes în managementul psoriazisului şi comorbidităţilor asociate. Practica Medicală 2016; 11,1(43):49-52.

10. Jahoda CA. Cellular and developmental aspects of androgenetic alopecia. Exp Dermatol 1998; 7:235-48.

11. Singal A, Sonthalia S, Verma P. Female pattern hair loss. Indian J Dermatol Venereol Leprol. 2013;79:626-40.

12. Stănescu AMA, Grajdeanu IV, Ştefani C, lancu MA, Şerban B, Bratu OG, Socea B, Diaconu CC. O meta-analiză şi review sistematic al prezenţei depresiei în rândul pacienţilor cu vitiligo. Practica Medicală 2019; 14,2(66):113-117.

13. Stefani C, Grajdeanu IV, Serban B et al. Abordarea depresiei în practica medicului de familie. Revista Medicală Română 2019; LXVI(1):24-28.

14. Ellis JA, Stebbing M, Harrap SB. Polymorphism of the androgen receptor gene is associated with male pattern baldness. J Invest Dermatol 2001; 116:452-5.

15. Hibberts NA, Howell AE, Randall VA. Balding hair follicle dermal papilla cells contain higher levels of androgen receptors than those from non-balding scalp. J Endocrinol 1998;156:59-65.

16. Heilmann S, Kiefer AK, Fricker N, Drichel D, Hillmer AM, Herold C et al. Androgenetic alopecia: Identification of four genetic risk loci and evidence for the contribution of WNT signaling to its etiology. J Invest Dermatol 2013;133:1489-96.

17. Price VH. Treatment of hair loss. N Engl J Med 1999; 341:964-73.

18. Hillmer AM, Hanneken S, Ritzmann S, Becker T, Freudenberg J, Brockschmidt FF et al. Genetic variation in the human androgen receptor gene is the major determinant of common early-onset androgenetic alopecia. Am J Hum Genet 2005; 77:140-8.

19. Ellis JA, Scurrah KJ, Cobb JE, Zaloumis SG, Duncan AE, Harrap SB et al. Baldness and the androgen receptor: The AR polyglycine repeat polymorphism does not confer susceptibility to androgenetic alopecia. Hum Genet 2007;121:451-7.

20. Prodi DA, Pirastu N, Maninchedda G, Sassu A, Picciau A, Palmas MA et al. $E D A 2 R$ is associated with androgenetic alopecia. J Invest Dermatol 2008; 128:2268-70.

21. Stănescu AMA, Grajdeanu IV, Serban B, Bratu OG, Socea B, Pantea Stoian A, Diaconu CC. Genetic implications in vitiligo 
and vitiligo-associated diseases. Arch Balk Med Union 2019; 54(1):161-165.

22. Li R, Brockschmidt FF, Kiefer AK, Stefansson $\mathrm{H}$, Nyholt DR, Song $\mathrm{K}$ et al. Six novel susceptibility loci for early-onset androgenetic alopecia and their unexpected association with common diseases. PLOS Genet 2012;8:e1002746.

23. Garza LA, Liu Y, Yang Z, Alagesan B, Lawson JA, Norberg SM et al.

Prostaglandin D2 inhibits hair growth and is elevated in bald scalp of men with androgenetic alopecia. Sci Transl Med 2012; 4:126ra34.

24. Midorikawa T, Chikazawa T, Yoshino T, Takada K, Arase S. Different gene expression profile observed in dermal papilla cells related to androgenic alopecia by DNA macroarray analysis. J Dermatol Sci 2004;36:25-32.

25. Cobb JE, Wong NC, Yip LW, Martinick J, Bosnich R, Sinclair RD et al. Evidence of increased DNA methylation of the androgen receptor gene in occipital hair follicles from men with androgenetic alopecia. $\mathrm{Br} \mathrm{J}$ Dermatol 2011;165:210-3.

26. Cervantes J, Perper M, Wong LL, Eber AE, Villasante Fricke AC, Wikramanayake TC et al. Effectiveness of platelet-rich plasma for androgenetic alopecia: A review of the literature. Skin Appendage Disord. 2018; 4:1-11.
27. Drăghici T, Negreanu L, Bratu OG, Tincu R, Socea B, lancu MA, Stănescu AMA, Diaconu C. Liver abnormalities in patients with heart failure. Archives of the Balkan Medical Union 2018;53(1):76-81.

28. Patwardhan N, Mysore V. Dermatosurgery Task Force. Hair transplantation: Standard guidelines of care. Indian J Dermatol Venereol Leprol. 2008;74(Suppl 1):S46-53.

29. FUE vs. FUT Hair Transplants: Overview. (Accesat: August 2019) Disponibil la: https://www.bernsteinmedical.com/ hair-transplant/fue/fue-vs-fut/.

30. Diaconu C, Bălăceanu A, Moroşan E. Sepsis biomarkers: Past, present and future. Farmacia 2015;63(6):811-815. 